\title{
Cosmopolitan Pleasures and Affects; Or Why Are We Still Talking about Yellowface in Twenty-First-Century Cinema?
}

\section{Felicia Chan}

\begin{abstract}
It is now widely acknowledged that the postracial fantasies ushered in by Barack Obama's two-term election success are now in tatters. Yet debates on yellowface casting practices in contemporary Hollywood (also said to have evolved into "whitewashing" practices), in such films as The Last Airbender (M. Night Shyamalan, 2010), Aloha (Cameron Crowe, 2015), Doctor Strange (Scott Derrickson, 2016), Birth of the Dragon (George Nolfi, 2016), and Ghost in the Shell (Rupert Sanders, 2017), have resurfaced in recent times. These press controversies seem almost anachronistic after a generation of "intercultural" artistic theory and practice, "diversity" management training, and numerous academic discourses on otherness and difference, including those on cosmopolitan theory and practice. This article reviews yellowface practices and debates in contemporary times and puts them in dialogue with cosmopolitan aspirations of being "open to difference", and argues that the latter cannot be taken as self-evident. It offers a way of thinking about yellowface practice via cosmopolitan pleasures evoked largely through modes of consumption, which "hollow out" the subjectivity of the character being depicted. On the site of the intersection between representation and subjectivity is where the identity politics occurs, yet, rather than universalising the issue, the article argues that a cosmopolitan approach should take on board localised conditions and contexts of production and reception in ways that acknowledge the multilayered complexity of the issues at hand.
\end{abstract}

Yellowface and cinema share their roots in the theatre. Writing about yellowface performance in the nineteenth century, Sean Metzger argues that the "Chinaman" fetish "substitutes for and conceals the dominant anxieties about Chinese immigrants among the white majority in the late 1800s [in America]" ("Charles Parsloe" 628), and the "Chinaman character serves as a vessel, encapsulating a range of anxieties produced by white concerns over the presence of Chinese people in the United States [sic] social and economic order" ("Charles Parsloe" 643). Indeed, yellowface performed as camp and comic representation via the racial impersonation of East Asian peoples (not only Chinese) by way of caricature extended well into the twentieth century-Mickey Rooney's short-tempered, buck-toothed and heavily bespectacled Mr Yunioshi in Breakfast at Tiffany's (Blake Edwards, 1961) still jars (Ito) - and also as figures of fear, such as the Fu Manchu figure in numerous books, films, television programmes, comics and radio. Jill Lane suggests that "racial impersonation - acting in the name of place of the other through such practices as blackface, redface, yellowface, cross-dressing, and drag - has played a particularly important role in the imagination and aesthetic articulation of national communities across the Americas" (1730).

Yellowface is now, by and large, perceived as an offensive and unacceptable practice, yet it persists, even in films as recent as Cloud Atlas (Lana Wachowski, 2012), in which actors Hugo Weaving and Jim Sturgess have their facial features altered with prosthetics to 
appear "Asian" in the film's fictional "neo-Seoul" city (Le). In the past few years, objections to a variation of yellowface have emerged largely online and in the social media, where Internet platforms have enabled disapproval to be voiced and debates to take place almost as soon as the casting is announced. The variation of yellowface has taken on the moniker of "whitewashing", a term referring to the casting of a Caucasian "white" actor in a non-white role, and in the case of East Asian roles, without necessarily employing the clumsy make up and prosthetics of the yellowface of old (though, as noted, the latter persists on occasion). Whitewashing could be known as racial appropriation or even displacement. Recent examples include Aloha (Cameron Crowe, 2015), in which Emma Stone is cast as a character called Allison Ng of part Chinese and Hawaiian descent, and Ghost in the Shell (Rupert Sanders, 2017), in which Scarlett Johansson is cast in the lead as Major Mira Killan, an ambiguous Europeanisation of the original Japanese manga/anime character Major Motoko Kusanagi. While these practices are not new, social media platforms have enabled a rapid mobilisation of activism around the issue in ways that previous media had not, ensuring that debates around yellowface remain foregrounded in the cultural discourse. An early example of this movement was prompted by the case of The Last Airbender (M. Night Shyamalan, 2010), a live-action adaptation of a popular animated series called Avatar: The Last Airbender (Nickelodeon, 2005-08), whose narrative universe is almost exclusively made up of East Asian and Inuit cultures, settings and characters. The film adaptation instead offered up an all-white cast, spurring fans and other activists to set up a movement online and on social media headed by a website known as Racebending, referring to the characters' abilities to "bend" elemental powers of air, fire, earth and water. Racebending.com has since evolved into an international grassroots organisation and advocacy group for fair racial and ethnic representation in the media beyond The Last Airbender (see Lopez), and it is partly its efforts, among other social media outrage, that are said to be responsible for the box-office failure of Sanders's Ghost in the Shell (Raftery).
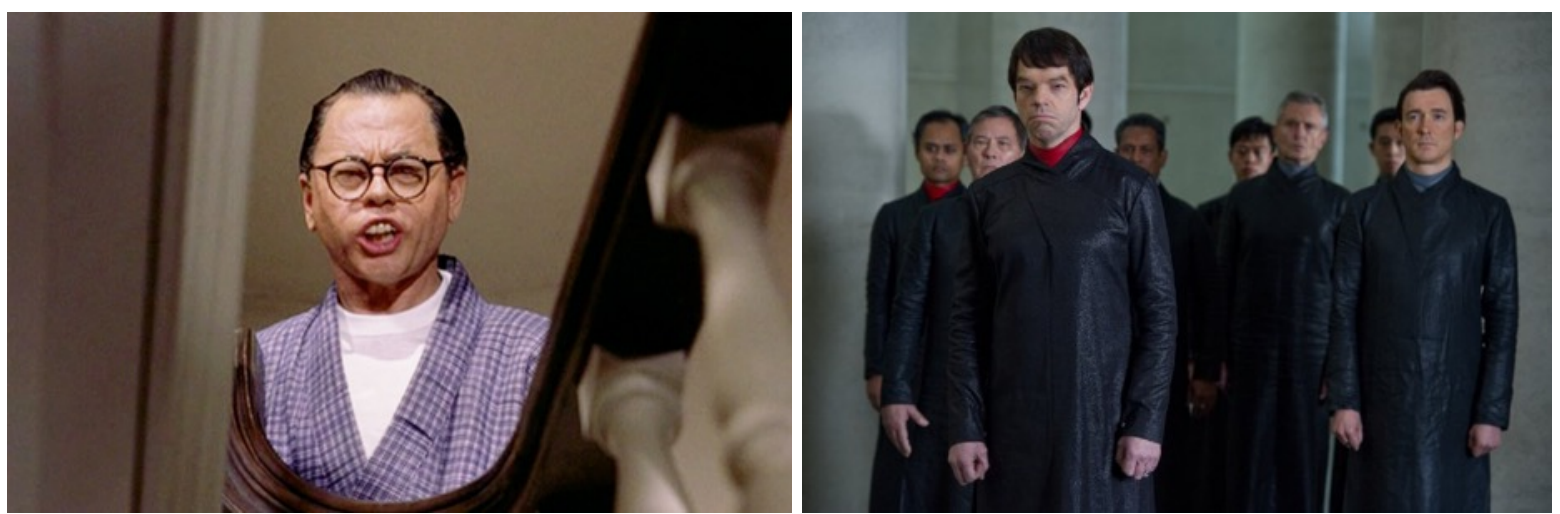

Figure 1 (left): Mickey Rooney as Mr Yunioshi in Breakfast at Tiffany's. Paramount Pictures, 1961. Figure 2 (right): Hugo Weaving (third from left) as Boardman Mephi in Cloud Atlas Warner Bros. Pictures, 2012. Screenshots.

Whitewashing is also used as a term to describe the denial of a film's racial identity or emphasis as a whole, not just a character's. For example, The Birth of the Dragon (George Nolfi, 2016), a biopic about Bruce Lee, the legendary Chinese American martial artist and actor, prompted fans to complain when the lead role did not feature Lee, but "a fictional Caucasian character, a young martial arts student, alongside Lee and Wong [Jack Man]" (Pulver). Producers of the film justified the decision by arguing that (white American) audiences required a point of identification into which they could enter the story. 
Whitewashing allegations are equally directed at The Great Wall (Zhang Yimou, 2016), starring Hollywood A-lister Matt Damon in the central role (Wong). That the film's director is the acclaimed Chinese filmmaker Zhang Yimou has not mitigated the situation.

Rather than racial impersonation, as was laid at the feet of yellowface practice, whitewashing is deemed by its critics to be an equally unforgivable act of racial appropriation, as it ironically eliminates the performative element of yellowface. Emma Stone (in Aloha) and Scarlett Johansson (in Ghost in the Shell) now stand in for an East Asian character without having to don the traditional (and, in themselves, troubling) markers of yellowface physiognomy and speech patterns: the "slit eyes", the sallow complexion, the pidgin English. What seems so particularly objectionable about whitewashing practice is the erasure of the character's Asian identity by the erasure of her body and presence on screen. Writing about blackface practice, Lane explains that "Impersonation ... relies on the 'fungibility' of blackness, in which the black body is imagined as an 'empty' vessel available for white occupation in every colonial sense of the word" (1730). The colonisation of the yellow body has most often been spoken of in terms of sexual possession of the female body, physically, narratively, or visually. This is epitomised by the persistence of the Suzie Wong/Madama Butterfly archetype as the meek (sometimes "fallen") oriental woman in need of rescue by the virile white male hero (see Chang). This arche-stereotype may be offensive but simply replacing it with an "unmarked" and undifferentiated white body (see also Dyer) is not the "simple" solution to a complex problem, as the producers of the Marvel blockbuster Doctor Strange (Scott Derrickson, 2016) found. In Doctor Strange, Tilda Swinton is cast as the Ancient One, a character who in the comics is a man and a sage of Tibetan origin. According to the director, the Ancient One's origins were changed from Tibetan to Celtic in an effort to avoid yellowface stereotypes. Derrickson's justification only agitated campaigners further (Sun), who were not convinced by his explanation that he could not envision the character except as a "Dragon Lady" stereotype, and so decided to avoid it altogether: "I just didn't feel like there was any way to get around that because the Dragon Lady, by definition, is a domineering, powerful, secretive, mysterious, Asian woman of age with duplicitous motives - and I just described Tilda's character. I really felt like I was going to be contributing to a bad stereotype" (qtd. in Evans, "Doctor Strange"; emphasis added). Derrickson's use of "by definition" is particularly resonant: "by definition" according to whom and whose definition? A stereotype is a cultural, political and historical construction. Yet, despite the media saturation of the early twenty-first century, the difficulty for Hollywood (and others, as will be discussed below) seems to be one of how to imagine Asianness beyond the "bad stereotypes". In other words, within the constitution of "Asianness" in these films is a disjunct between appearance and subjectivity, for which activists for Asian-American identity struggles desire a claim.

Where and how can cosmopolitanism and cosmopolitan debates intervene in this discursive impasse? In this article, it is through the frame of cultural appropriation as consumption that I wish to explore renewed questions of yellowface in contemporary film alongside the frame of cosmopolitanism as a (conflicted) mode of engaging with difference. Cosmopolitanism as a conception and a practice of experiencing and being in the world can be fraught with contradictions. As an ideal, cosmopolitanism signals an openness to difference or, as Jackie Stacey puts it, "an ease of proximity to the unfamiliar" ("Uneasy Cosmopolitans" 163). In practice, it often has to contend with border conflicts, xenophobia and parochialism. There is an aspirational dimension to cosmopolitanism that is attractive, yet critics like David Parker are suspicious about its professed universalism, arguing that the "terms on which cultural differences are encountered, appropriated and absorbed have never 
been free from power; from being embedded in the asymmetrical relationships and pressures of commerce, colonialism and military force" (156). Yellowface as an (objectionable) cultural practice is the result of such asymmetrical relationships and practice.

Debates about cosmopolitanism have largely taken place within the social sciences and political philosophy, particularly after 9/11, and applied to "real world" contexts and questions of citizenship and belonging, especially where they exceed national boundaries. More recently, scholars in art, literature, film and media have taken to engaging with cosmopolitan arguments through the imaginative spaces that these art forms provide (see Chan, Cosmopolitan Cinema; Meskimmon; Papastergiadis; Schoene; Spencer). Within these spaces, encounters with difference can be enacted and explored, even confronted. In this article, I focus on the cultural production and reception of yellowface, viz. the cosmopolitan pleasures and affects it produces. I am less interested in how we can "better" represent the other in film by being more "open to difference" (although there is always more room for this), but rather in how contemporary yellowface practice continues to challenge us to interrogate the terms of such "openness". Under what psychosocial conditions and contexts are these practices and prejudices produced? And in what way can a cosmopolitan disposition help us understand how they operate? I present my analysis in two parts: firstly, how the pleasures of consuming difference maintain a hold on cosmopolitan outlooks and experiences, reproducing, rather than ameliorating, "the very social divisions cosmopolitanism claims to dissolve" (Molz 39); and, secondly, how the affects produced by yellowface performance may help us understand why alternative representations of "Asianness" seem difficult to imagine - and, by the latter, I also mean the Asianness that operates likewise as a cultural other to Asian cultural producers and spectators. In other words, there is a bifurcation between yellowface Asianness, consumed as media and cultural commodity, and a kind of yet-unmarked/unnamed/untranslatable Asianness which seeks not to be yellowface, yet struggles for representation even by Asian cultural producers themselves. Here, I am taking it for granted that "Asianness" is understood to be a contested conception, whose very multifariousness is at the core of our discursive predicament.

\section{Cosmopolitan Pleasures}

Cosmopolitanism has been theorised as an outlook, a disposition, a mode of cultural practice, and a way of experiencing the world. Yet it is often first experienced as a mode of consumption, usually as "world" foods, fashion, and cultures, constituting what Ulrich Beck calls "banal cosmopolitanism" (10). Such banal cosmopolitanism, Beck argues, "pervades ... spheres of everyday culture" (41) and can be found in most cities and urban centres. Indeed, this form of consumption is often taken to be an expression of urbane modernity.

In her research into the history of Selfridges, one of London's flagship department stores, Mica Nava uncovers a form of cosmopolitan practice she links with commodity consumption and modernity, including that presented at the cinema. In offering the wares of the world for sale in one enormous store, Selfridges, Nava notes, consciously promoted foreign products and styles, the desire for which was fuelled by such exotica depicted in "the massively popular post-war genre of desert romance novels and films like The Sheik [George Melford, 1921] (in which Valentino starred)" (85). These "evoked a narrative of otherness, a kind of 'elsewhere' of the imagination, which had a particularly libidinous investment for women and an appeal which appears to have transcended class barriers" (85). When Siegfried Kracauer expressed disdain for the "shopgirls" who went to the movies, he was precisely 
referring to this new culture of consumption that marked the new modernity of the early twentieth century. Kracauer's quarrel with the "[s]tupid and unreal film fantasies" was that their fuelling of the desires of the newly income-independent shop girls in this period stood in for "the daydreams of society, in which its actual reality comes to the fore and its otherwise repressed wishes take form" (304; emphasis in the original). Nava's analysis, I believe, goes further than Kracauer's and Beck's when she argues that this mode of consumption saw not only the consumption of foreign goods and fashions, but also the transformation of "the intimate spheres of the body and [penetration of] the home" (85). These foreign fashions were "incorporated into the culture" and "signalled fusion and identification" (Nava 85). In other words, taken together, acts of representation coupled with desires for consumption underpin the internal contradictions and ambivalences of the cosmopolitan disposition. Nava notes that:

Unlike the exoticizing narratives identified by critics of orientalism-in which "other" women are cast as objects of sexual desire and the oriental landscape is represented rhetorically as erotic female - in the cosmopolitanism of the commercial and entertainment spheres, women appropriate the narratives of difference for themselves in contrary and even polemical ways. (85)

Yellowface practice in films can be read within these contexts. Molz argues that the banal cosmopolitanism of the consumption of the cultural other promotes the appearance of a kind of cultural competence, "an intellectual skill, an aesthetic savoir faire, and affective pleasure in experiencing and navigating through cultural difference" (35). As such, it is possible to read contemporary yellowface practice as a latter-day form of chinoiserie, a hangover from the days when European empires collected oriental artefacts for display in their own domestic domains as a symbol of their worldliness, or more importantly, their domination over other territories and cultures. More than that, though, chinoiserie more accurately refers to the desire for the ownership of such artefacts, regardless of their point of origin. Chinoiserie is, in fact, an aesthetic practice, where European manufacturers of porcelain, furniture and other bric-a-brac, imitated Chinese materials and decoration for sale to European domestic markets (see Smith). Read within this context, contemporary yellowface and its new bedfellow, whitewashing, in recent films can be seen as furthering this consumerist practice. I argue that whitewashing can be read as the logical extension of yellowface, once cultural representation became divorced from human agency and subjectivity, i.e. "hollowed out", and began to be consumed as commodified artefacts.

While the practice of racial impersonation has also always gone hand in hand with cultural consumption by way of commodities - the appropriation of black music by way of blackface minstrelsy is one example - in the case of chinoiserie, the form of consumption takes on a particular inflection. Writing about eighteenth-century England's fascination with chinoiserie, David Porter describes its heights: "Extravagant spectacles featuring Chinese costumes and ornaments drew crowds to the theaters. Chinese plays were adapted and widely performed. A craze for chinoiserie furnishings and architecture transformed sitting rooms and gardens across the country" (28). Porter's reading of this phenomenon bears a close similarity to Beck's banal cosmopolitanism, when he argues that:

The collectors and consumers of vast quantities of Chinese or Chinese-inspired porcelain, wallpapers, lacquerware, silk and furnishings that circulated through all of Europe in the eighteenth century remained generally oblivious of the ambitions of an 
earlier generation of missionaries and philologists to "know" China, to render legible its vast universe of endlessly perplexing signs. (Porter 28)

These consumers were, he continues, "content simply to enjoy a delicious surrender to the unremitting exoticism of total illegibility. To luxuriate in a flow of unmeaning Eastern signs, to bask in the glow of one's own projected fantasies, such were the pleasures afforded by China's arrival in the marketplace of contemporary taste" (28). Chinoiserie, he concludes, "was an aesthetic of the ineluctably foreign, a glamorization of the unknown and unknowable for its own sake" (28). To consume these luxurious and exotic goods was to be cosmopolitan and modern. Replace "chinoiserie" here with "yellowface" and much of this reading still applies.

Porter's analysis of chinoiserie as a "hollowing out" of cultural (and human) agency is particularly relevant to my attempts to think through the persistence of yellowface here. In reducing the pleasures and affects of consuming aspects of a culture to such aestheticised features, the consumer (and perhaps the producer, too) bears no responsibility to the agency of any representatives of the culture at large. And what is also interesting, but less frequently addressed, is that the newly modernising East Asian societies are also rapidly producing fastspending consumers equally keen to possess such orientalist artefacts as a marker of modern style and living promoted in Western lifestyle magazines with global circulations. As recently as March 2017, Vogue magazine came under strong criticism for featuring American model Karlie Kloss heavily made up as a Japanese geisha in a six-page photoshoot titled "Spirited Away" (a reference to the Studio Ghibli film from 2001). The spread formed the central feature in Vogue's "diversity issue"; an editorial decision made apparently without irony.

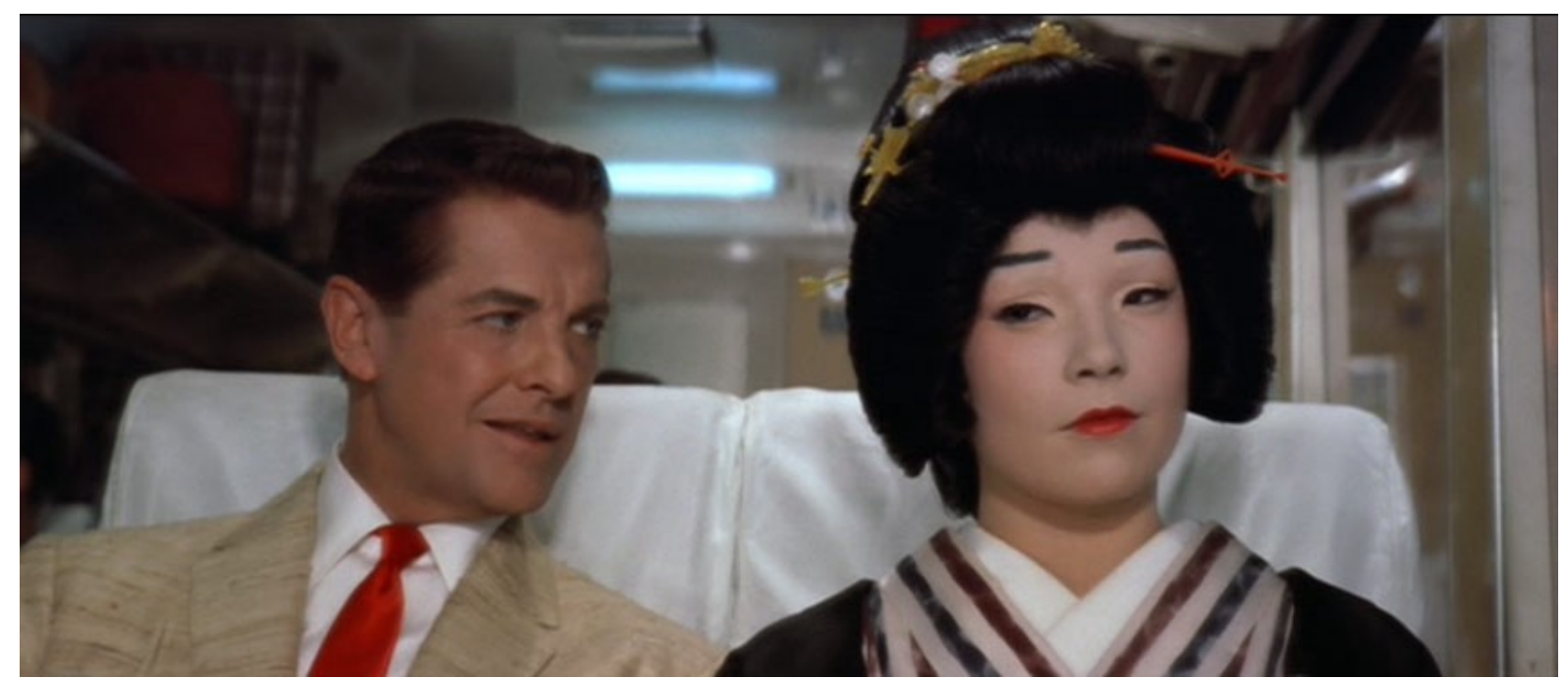

Figure 3: Shirley MacLaine (right) as Yoko Mori in My Geisha. Paramount Pictures, 1962. Screenshot.

So just like a "Chinese style" vase or draping that could be made in European factories and sold to European audiences, yellowface becomes another "Chinese style" performance that could unproblematically be performed by the non-Chinese to be sold to European and westernised audiences. Thus, as Robert Ito notes:

As recently as 1995, Penny Delamar's The Complete Make-up Artist had two listings under the category "Ethnic Appearances"-_Caucasian to oriental" and "Caucasian to 
Indian," complete with really sick before-and-after photos of a young blond woman made up to look like Fu Manchu. ... To contemporary viewers, these eyepieces and cosmetic techniques look, to put it kindly, like crap. The actors don't look Asian at all, but exactly what they are: white actors wearing a weird combination of eyepieces, rubber bands, and makeup. Incredibly, legendary Hollywood makeup artists would look back with pride at their earlier works, marvelling at their realism and believability. In 1976, Frank Westmore, who did the horrendously awful work on Shirley MacLaine in My Geisha, said in his memoirs that the actress "looked as Oriental as the Japanese Empress." Don't believe it. She looks ghastly, and unmistakably Caucasian.

The question of physiognomy has always been central to racial identity politics, viz. non-white ethnicities in the West. Writing about early Eurasian/Amerasian women's texts, Helena Grice explores how writers sought to "interrogate the relationship between exterior and interior subjectivity" and how this "relates to their position as liminal ethnic subjects in the United States" (255). Yellowface cosmetics, as described above, conduct no such interrogation. They operate as figurations, as masks that signify the role. Interrogating their function requires acknowledging the presence of a subject, which the mask either points to or hides. It is these figurations, devoid of subjectivity, that also precisely enable these images to continue to circulate in the popular culture. For instance, the "Fu Manchu look", with the thin moustache, narrow eyes and arched eyebrows, is said to have heavily influenced the depiction of the Klingons in the original Star Trek series.

This hollow aestheticisation of "Chineseness" or "Asianness" in these forms can go some way to explain the "self-orientalisation" that certain Chinese directors, such as Zhang Yimou, have previously been accused of. In an earlier essay (Chan, "Filming China"), I argue that Zhang has skilfully negotiated the visual politics of his films according to the political and commercial contexts of the time. If Zhang's early films (e.g. Judou, 1990; and Raise the Red Lantern, 1991) may be read as ambiguous orientalist allegories, there is very little ambiguity in his over-the-top production of Puccini's Turandot at Beijing's Forbidden City in 1998. Sean Metzger called it a "spectacle of excess": "Zhang Yimou's staging exaggerates European fantasies of the Chinese other and materializes them onstage" ("Ice Queens" 212), employing for instance martial arts exponents and Chinese dancers into the choreography and embellishing the costumes with bright hues of pink, yellow or red, complete with a "huge butterfly head ornament" (212) in one instance. Zhang's Turandot, it could be said, presented itself as more "Chinese" than Chinese, and Metzger concludes: "I think Zhang Yimou has mobilized an aesthetic of excess to create an Intercultural Fantasy Island" (214). Indeed, given the context of Zhang's other work, it is not far-fetched to assume that these aesthetic decisions were knowingly made, almost as a challenge to the Western gaze to accept their performance of authenticity. Was that challenge adequately met? The orchestral conductor for the staging, the internationally renowned maestro Zubin Mehta, purportedly declared: "Usually Turandot is full of Chinese clichés. It looks like a big Chinese restaurant. But I think this is really different because this is really authentic. We didn't really invent anything. This is really it" (qtd. in Yang 8). Can a cliché of a cliché really make an intervention in representational politics? Yiman Wang describes the performances of Asian American actress Anna May Wong as those of "yellow yellowface". Wang argues that:

To make Wong's legacy better serve Asian American interests, I would like to consider ... her performative strategy of passing, or more specifically, screen passing. By screen passing, I mean her ability to act and overact in a wide range of racialized 
roles, by which she brings to the fore the stereotypical and Orientalist underpinnings of these roles. (160-61; emphasis in the original)

Arguing that this performative strategy has been "discursively repressed" (161), Wang analyses how Wong's performance took her beyond functioning as a "mere index of a homogenous Orient" (161), by employing a "camp aesthetic" generating an ambivalence that is "handled by maintaining, through the rhetorical overlay that is stylization, a special distance from the subject" (176). Wang reads Wong's yellow yellowface within a broader "art deco aesthetic" (167), whose decorative arts signalled both luxury and modernity and, significantly, the pleasures of both. In other words, Chinese cultural production appears to have to overplay and overperform its cultural stereotypes in order to justify its "representation".

This aesthetic economy is, thus, also a political economy and, as a corollary to yellowface, whitewashing emerges as the natural occupier of the hollowed-out space originally created by the consumptive pleasures of chinoiserie described above. Once the responsibility for representation is deflected onto the economics of consumption, the economic logic (even if flawed) for whitewashing practice is then frequently used as a justification; the (lazy) assumption that audiences want to see a bankable (white) star in the lead frequently asserts itself. Devoid of the yellowface masks and prosthetics to read against, determining a case of whitewashing requires one to identify the absence (of Asian representation) rather than presence of the (white) mask. This is what makes it so difficult and frustrating for critics of whitewashing to make their point.

The banal yellowface or whitewashing practice of films like Aloha, Doctor Strange, Ghost in the Shell and The Last Airbender can be seen to draw parallels with Beck's banal cosmopolitanism, in that the cultural artefacts of the other are consumed without knowledge or, more importantly, acknowledgement of the other's agency. As Molz puts it:

On the one hand, the forms of aesthetic or banal cosmopolitanism ... entail a desire to consume cultural difference. On the other hand, the very act of consuming difference results in, at best, a hollowing-out or watering-down of that difference, and at worst, a form of appropriation and symbolic oppression of the Other. ... If consumption eradicates difference, then cosmopolitan consumption seems to be an impossible proposition. (38)

There are dangers to claiming these forms of consumption for cosmopolitanism, as Molz argues; for while "[c]osmopolitanism often entails fantasies of transcending cultural differences, ... consumerist ideology tends to reproduce the very social divisions cosmopolitanism claims to dissolve" (39). However, more than merely denoting these forms of consumption as undesirable, a multilayered approach may be needed to understand or, at least, acknowledge in the first instance, the pleasures it generates. In an example as far back as 1968, Mary Malone, writing about London's and Liverpool's Chinatowns for the Daily Mirror, appeared to recognise the stereotypes about Chinese cultures that were perpetuated as "comic-book hogwash", but nevertheless closed her article with an ironic observation: "It's all very well ripping away the myths like this, but now what are we going to do for an exotic night out?" (18). ${ }^{1}$

The struggles against yellowface, however, are of course about people, communities and identities, and not only artefacts or commodities; nor am I suggesting that people are 
reduced to commodities. What I am arguing for is an interrogation of structures of knowledge and cultural production and an understanding of the points at which these intersect with human lives, on many occasions as points of friction, and where complex affects are produced.

\section{Cosmopolitan Affects}

This discussion on cosmopolitan affects takes its cue from Jackie Stacey's analysis of cosmopolitanism and the psychoanalysis of groups. In her essay, Stacey interrogates a fundamental premise in cosmopolitanism that is frequently taken for granted, that of being "open to difference". Debates are often more concerned with how we can be more open to difference. However, Stacey questions a premise more fundamental than that. She asks:

What might it mean to be open to difference? ... how do we know when others are open to the differences we represent and vice versa? What is the register of such openness: is it cognition, intention, affect, viscera? And difference in relation to whom or what exactly? What kind of openness is at the centre of such claims: celebration, neutrality, tolerance, indifference, recognition? And what is the register of the success and failure of such an aspiration? Is it simply the absence of aversion, or is it the presence of something quite tangible? ("On Being Open" 45)

When addressing issues of identity politics, it may be worth reconsidering some core questions, such as: what does equal representation mean? How might it be achieved? Would it take the same form in different contexts? Stacey asks in addition: "Is openness to difference a transparent and self-evident phenomenon? If we were to aspire to such a disposition, how would we know if we had achieved it?" (“On Being Open” 48). By not taking the notion of "openness to difference" as transparent and self-evident, I explore contemporary issues of yellowface in two areas: firstly, the issue of labour and the human cost of (stereotypical) representation; and, secondly, the contexts (and economics) of production and reception.

One central problem for yellowface practice and stereotyped representation in Hollywood film has been the issue of work for Asian American (and, in the British context, British East Asian) actors. In the documentary Hollywood Chinese (Arthur Dong, 2007), Tsai Chin freely admits, when asked why she accepted the role of Lin Tang, Fu Manchu's daughter, in at least five films of the franchise, that it was simply because it was "work", i.e. employment that paid the bills. ${ }^{2}$ As Chang notes: "Even as Asian actors began to break into film in the post-exclusion era, they often found themselves needing to acquiesce to stereotypical portrayals defined by white film-makers in order to find work, such as Nancy Kwan did with her role as Suzie Wong" (261-2). ${ }^{3}$ Both actors are still active in Hollywood, though now sometimes still cast in stereotypical Asian "auntie" or "grandma" roles, such as Tsai's in Memoirs of a Geisha (Rob Marshall, 2005). This conundrum between playing to stereotype and playing the role for the work persists in the frustration expressed by Asian American actors ${ }^{4}$ about being overlooked for roles such as Tilda Swinton's Ancient One. In her "open letter" to Swinton, Rebecca Sun writes:

First, some useful context on the state of Asian representation onscreen. Among the 100 top-grossing movies released last year, just 3.9 percent of characters who had lines or even names were Asian. Forty-nine (in other words, basically half) of those films had no named or speaking Asian characters at all. It should go without saying 
that not one lead or co-lead in 2015 was played by an Asian actor. (That's not to say there were no Asian characters. The 100th-highest-grossing film in 2015 featured a female love interest who was a quarter Chinese and a quarter Polynesian. Her name was Captain Allison Ng, the movie was Aloha, and she was played by Emma Stone.)

On the one hand, there is the paucity of Asian characters, and on the other, what is available appears to be offered to Caucasian actors.

What sometimes adds insult to injury is that the latter's performance is then considered a matter of performative skill (as with the make-up artist above), rather than racial indexicality. As Yiman Wang notes, no matter how skilled Anna May Wong may have been in her roles as a "Chinese" character, she was not necessarily seen to be doing anything extraordinary:

when a white actor acts in yellowface or blackface, he or she is taken as a skillful performer of someone apparently not him- or herself, hence the impossibility of conflating the actor with the role of the racial Other. For a non-white actor, however, his or her transitive and mimetic connection with racialized roles remains fixed. In these terms, Wong's acting could only be evaluated on the basis of how Chinese it appeared to be. (168)

Of course, non-white actors are very rarely cast in roles that typically go to Caucasian actors - some exceptions include The Fast and the Furious franchise (see Beltran) — closing the circuit of representational invisibility.

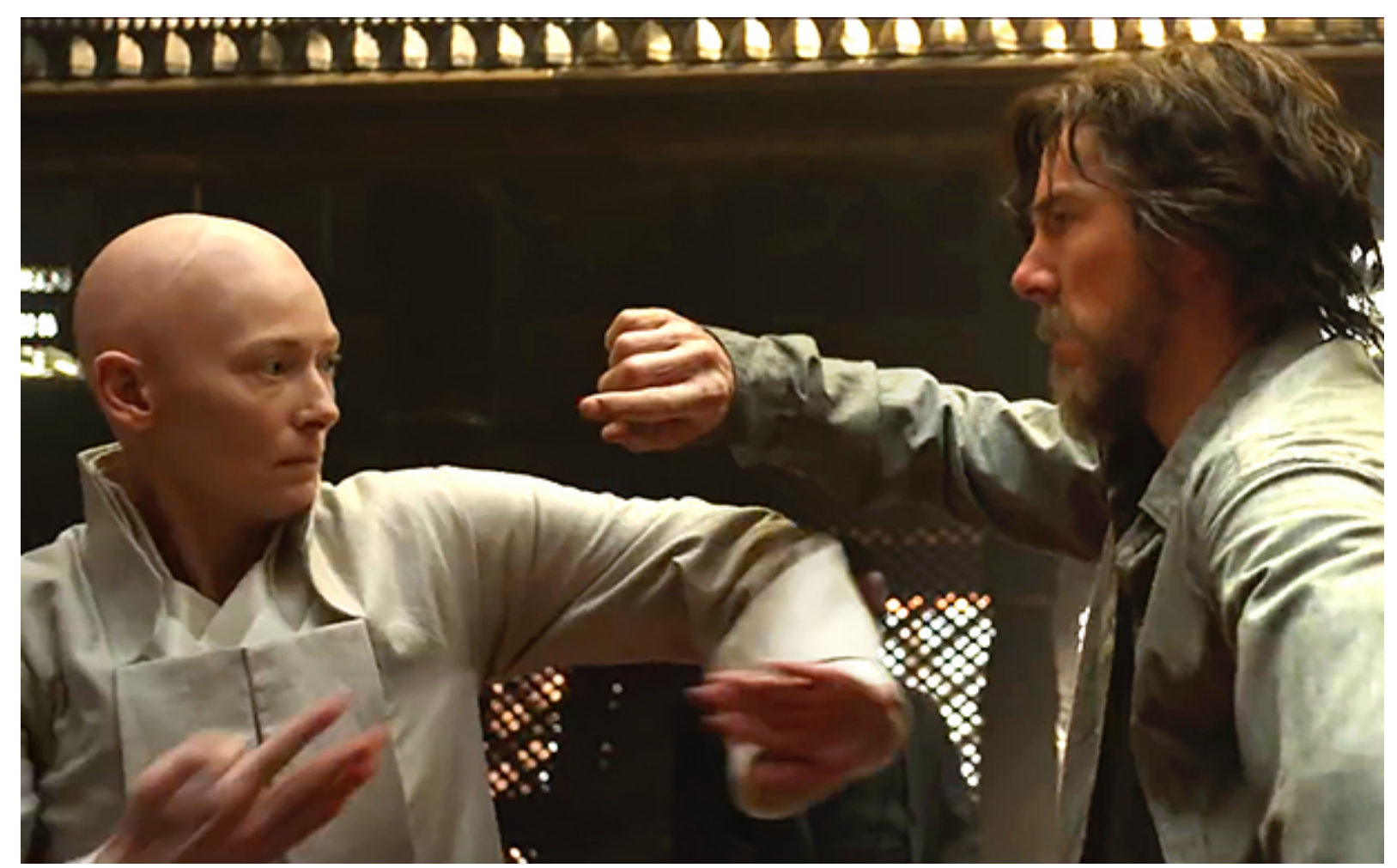

Figure 4: Tilda Swinton as the Ancient One (left) in Doctor Strange. Walt Disney Studios, 2016. Screenshot. 
No amount of pronouncements about the need to be "open to difference" will help the situation if being open to difference simply means being open (aka "tolerant") to stereotypical representations of racial communities. Thus, I tend to be cautious, if not sceptical, for unending calls for "diversity" in the film and media industry. "Diversity" is not something that requires "doing" by way of a boardroom decision or policy document, as often such calls to diversity simply reinforce the consumerist aspects of racial representation. "Doing diversity" by simply including more Asian faces in the casting is not the answer to a problem that has more affective resonances, as illustrated by the curious outcome of the correspondence exchange between Tilda Swinton and Margaret Cho, a Korean American actress, on Swinton's role as the Ancient One in Doctor Strange. Swinton, who had never met Cho, apparently sought the latter's advice and explanation for the outrage that ensued. Swinton's puzzlement seemed genuine and her efforts to "understand" sincere, and she finished the conversation by revealing that she is producing a film with a Korean director and an Asian cast, expressing the hope that it will "help the landscape somewhat" (for the full exchange, see Juzwiak). However, Cho was later reported to have felt "like a house Asian" (i.e. domestic servant) following the encounter (Sun), which prompted Swinton to release the full transcript of their correspondence to the press. On the surface, Swinton's words and intents were perfectly sincere, but to Asian Americans (and others engaged in decades of identity struggles) her very desire to seek understanding in this "sincere" way is a source of frustration. Here are what I see as several sticking points. Firstly, in approaching Margaret Cho, whom she had never met, simply because Cho is a high-profile Asian American, i.e. Cho is treated as a "representative" of the oppressed community. Secondly, in asking the oppressed to explain why they are feeling oppressed in order to "understand"- the oppressed should never be asked to "explain" their position. In the words of Audre Lorde:

Black and Third World people are expected to educate white people as to our humanity. Women are expected to educate men. Lesbians and gay men are expected to educate the heterosexual world. The oppressors maintain their position and evade their responsibility for their own actions. There is a constant drain of energy which might be better used in redefining ourselves and devising realistic scenarios for altering the present and constructing the future. (115)

Thirdly, in citing her own identity as a 55-year-old Scottish woman as akin to understanding how it feels to be marginalised - the histories are completely divergent and doing so constitutes another form of identity appropriation. Fourthly, in offering "help" by way of making a film with Asian people in it, without recognising that Asians working in Asia then occasionally in Hollywood experience race relations in Hollywood completely differently from Asian Americans. In fact, the presence of Asian actors from Asia in the American industry is contributing to the continued erasure of Asian American representation in Hollywood. In addition, the size of the market in the People's Republic of China (PRC) is drawing Hollywood to its shores and that market seems relatively unperturbed by yellowface as hungry for spectacles (of excess). Doctor Strange made over US\$110m in the PRC alone and over US\$677m worldwide. In fact, Chinese investment is increasingly pouring into the Hollywood product and seems happy enough to sell whitewashed stereotypes (see Kokas). Indeed, it has been suggested that the casting of Tilda Swinton as a Celtic mystic in Doctor Strange was in part due to the producers' desire to not represent Tibet onscreen and risk a screening ban by the Chinese authorities, and eliminate the fastest growing market for Hollywood fare. The casting of a woman in a male role, and perhaps Swinton in particular as a famous "trans" figure herself (see Stacey, "Crossing Over"), was expected to ameliorate "the bad choices that had to be made" (Wong, "Doctor Strange"). Its failure to do so points 
again to the fruitlessness of too easily conflating the terms and politics of one struggle (gender) with another (race). Unsurprisingly, this move was also lamented for subjecting Tibetan representation onscreen to erasure (Shaw-Williams, "Doctor Strange"). Market considerations may have picked the side of economic profitability and political expediency, but that should not prevent us from analysing its discursive outcomes, and these particular instances have provided useful case studies from which to explore complex questions. So to reiterate, any address of "openness to difference" must take into account the contexts in which they operate, and in the case of film, especially economic and political contexts which produce discursive affects. As Stacey notes in her inquiry, "what if one's own sense of openness to difference might appear to others as closure, assimilation or even appropriation or incorporation?" ("On Being Open" 51). This is not to say that the struggle for representation should cease. Indeed it remains important for those fighting for work within the industry, which leads me to questions of production and reception contexts.

In Cosmopolitan Cinema, I argue for the importance of engaging with localities and specificities as a way of mitigating the (hegemonic) universalising force of cosmopolitanism. A cosmopolitan outlook could be "open" not to "difference" as such, but to the conditions for which difference is enacted and received. If Western cultural production (within this I include Chinese directors working in the West or on projects seeking a Western address) cannot imagine Chineseness beyond certain featured stereotypes, and the Chinese cannot appear Chinese unless they play up to those stereotypes, then how can we speak of "representing" Chinese at all? I raise, as a brief case in point, Isaac Julien's nine-channel video installation, Ten Thousand Waves, which opened at the Sydney Biennale in 2010. Since his debut with Looking for Langston (1989), Julien has developed as an artist and a filmmaker focused on exploring issues of black and gay identity in Britain. Ten Thousand Waves can be said to be his first "Chinese" project. It is said to be "a tribute" to the twenty-three undocumented Chinese immigrants who died in Morecambe Bay in 2004 while picking cockles. What interests me about this project is Julien's representation of "Chinese" appears to fall back on known (and precirculated) images, and particularly: (1) the presence of Hong Kong actress Maggie Cheung dressed in the period costume of Chinese martial arts films suspended from the ceiling with her hair and robes floating behind her, specifically reminiscent of her role in Zhang Yimou's 2002 Hero, one of the few Chinese-language films to have wide global distribution (see Rawnsley and Rawnsley); (2) the presence of Chinese actress Zhao Tao who is internationally recognised as the lead actress in the films of arthouse director Jia Zhangke; and (3) the clips from the Chinese classic film from the silent era, The Goddess (Wu Yonggang, 1934). The installation itself is complex enough to warrant a full study of its own, but for the purposes of my argument here, the question is one of how these indexical images of a kind of "global", homogenised, Chineseness are expected to resonate with the tragic deaths of those at the mercy of, ironically, global capitalism. Albeit not in the tone of the costumed caricatures of Zhang Yimou's Turandot, these images of classic and contemporary Chinese cinema are nonetheless ones that are readily available, and recognisable, and thus consumable to the West. The video sequence even opens with a calligrapher writing Chinese words ("Ten Thousand Waves") onto the screen. Because the installation has been purchased by museums around the world (including New York's Museum of Modern Art, and most recently jointly by the Towner Gallery in Eastbourne and the Whitworth in Manchester for $£ 80,000)$ these images are continually reprised for Western "cosmopolitan" consumption, even when spoken of as a "homecoming" to the north of England (Brown). The "local" on this occasion, whether of Morecambe, the north of England, or the plight of the Chinese migrants cannot really compete with the scopophilic power of the Chinese exotic once again. 
Localised conditions of reception can also differ in their specificities. While the whitewashing in Ghost in the Shell received harsh criticism from its Western fan base, Japanese audiences did not seem to mind Scarlett Johansson's casting. Emily Yoshida reports that, when interviewed in the streets, young Japanese seemed "genuinely flummoxed as to why American audiences would be opposed to the casting" (Yoshida). Japanese audiences, she argues, "unlike American audiences, don't understand Motoko to be a Japanese character, just because she speaks Japanese and has a Japanese name" and that this speaks to "the racial mystery zone that so much anime exists in, allowing viewers to ignore such unpleasant dynamics as oppression and discrimination even as they enjoy stories that are often direct responses to those dynamics" (Yoshida). Yoshida cites Yuta, the Japanese vlogger who went out to interview his contemporaries about Johansson's casting; he says: "My biggest challenge of this interview was to explain what whitewashing [is], because it's not something Japanese people usually think about" (Yoshida). This is borne out by my own anecdotal experience teaching about the politics of yellowface at a UK university. I show examples from Charlie Chan to Fu Manchu, The Good Earth (Sidney Franklin, 1937; with Paul Muni and Luise Rainer as Wang and O-Lan respectively) to the Kung Fu TV series (1972-1975) starring David Carradine and, in general, it is my British and European students (both Caucasian and otherwise) who are aghast. Students from China tend to be more bemused by the comic caricatures than offended; there appears to be no ownership of these characters on their part, and yellowface seems to be accepted as something that Euro-American filmmakers do. Likewise, when I posted Andrew Pulver's article from The Guardian onto my Facebook page, the negative response (from friends and friends of friends in Singapore) was not so much directed at the presence of the fictional Caucasian, as the fact that the Wong Jack Man figure in the photograph accompanying the article was dressed inappropriately in saffron robes, an attire reserved for monastics; the real Wong Jack Man is a contemporary figure who taught classes at the Fort Mason Center in San Francisco.

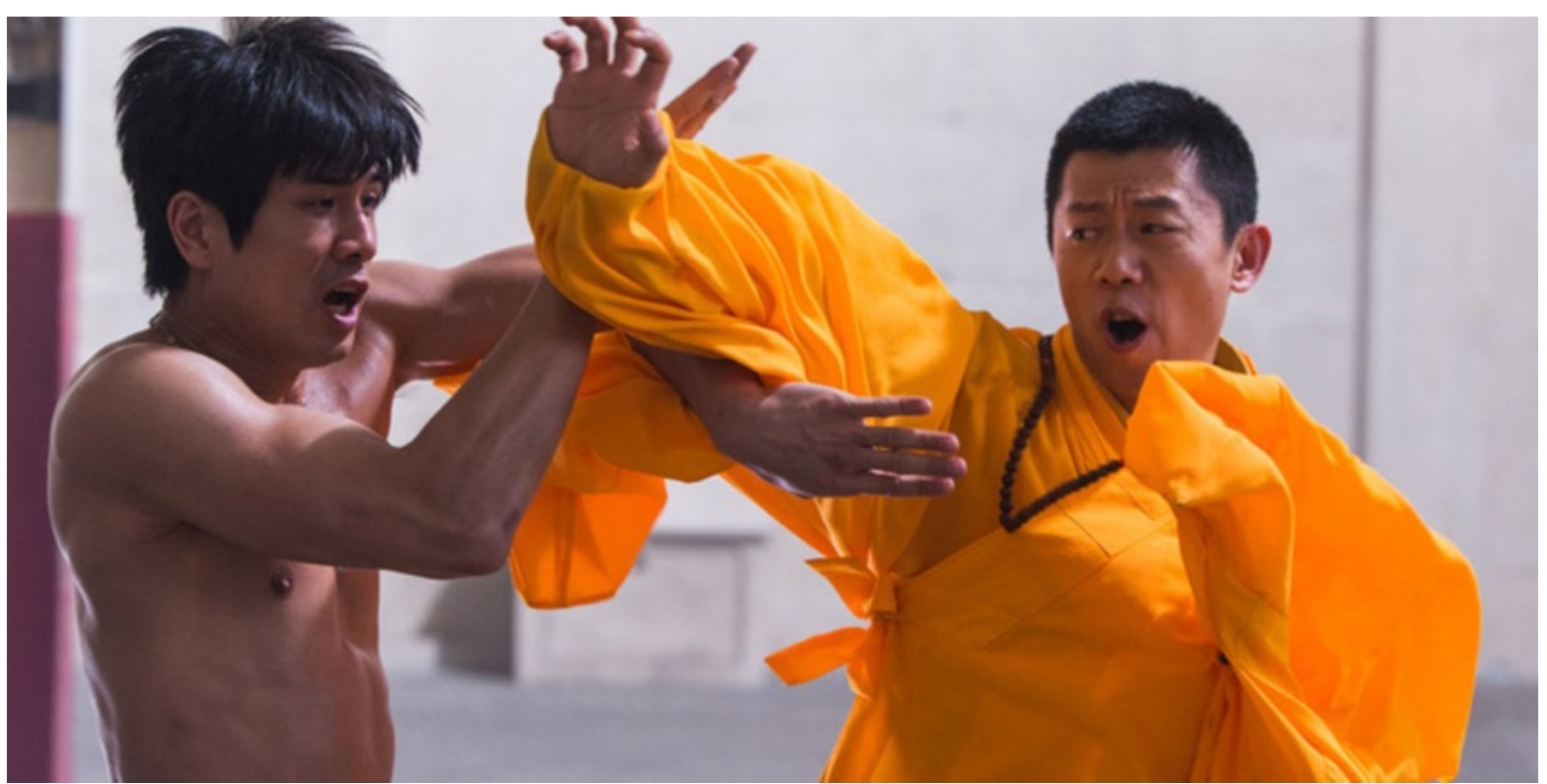

Figure 5: Yu Xia as Wong Jack Man (right) in The Birth of the Dragon. Groundswell Productions, 2016. Screenshot.

Once again, such representation can often speak to a political economy of cultural production as well as reception, perhaps none more resonant than with the geopolitics of 
casting of The Great Wall. Zhang Yimou, the filmmaker, has denied any whitewashing practice, arguing that the narrative necessitated the presence of a "foreign mercenary", thus the "natural" casting of Matt Damon in the central role. Zhang goes as far as to note "with a laugh" that Damon "actually uses Mandarin to say the word 'trust' and he says it very well. And up to our Chinese standards" (quoted in Loh, "No whitewashing"). There is no overt anxiety about a cultural erasure expressed here and, ironically, the film's entry into the Hollywood pantheon appears to signal the ultimate "arrival" and acceptance of a Chinese filmmaker and actors into the Hollywood mainstream (Nguyen, "With The Great Wall"). However, as Kevin Nguyen articulates, "whitewashing isn't just an issue of casting. It's a matter of audience." He compares its politics of reception between audiences in China and those in America, where Asian American struggles for identity continue to be fought: "Since most Chinese films star Chinese actors, representation isn't the same concern for audiences as it is in the U.S. To audiences in a Beijing movie theater, a white guy showing up at the Great Wall to fight dragons isn't just one more in a relentless series of slaps in the face from a system catering to white audiences" (Nguyen, "With The Great Wall").

Thus, the affect of cultural appropriation and of being "open to the difference of others is not a self-contained state of mind, nor is it predictably a continuous one; it is a constant negotiation of shared uncertain affective terrain" (Stacey, "On Being Open" 52), and engaging with these contexts requires an openness not to abstracted notions of "difference" or "diversity", but an awareness of how much comprehension depends on engaging with the specificities of geography, history and sociopolitical frames of reference. As Pheng Cheah has argued, "the ethico-political work that ... cosmopolitanism can do at any given moment depends on how either formation emerges from or is inscribed within the shifting material linkages and interconnections created by global capitalism at a particular historical conjuncture" ("The Cosmopolitical-Today" 31). Understanding this negotiability does not, in any way, diminish the negative force of yellowface, especially on diasporic communities who have had to endure the effects of its prejudice for generations, as well as its impact on self-identity. Yoshida distinguishes her own experience of anime as a Japanese American, "who grew up forced to think about identity in a much more tactile way", from those of Japanese people living in Japan:

For us, anime is something from our country, or our parents' country, that was cool enough for white kids to get into just as fervently. We couldn't see ourselves in Hollywood's shows and movies, but we could claim anime as our own, and see ourselves in its wild sci-fi imaginings and cathartic transformation sequences. (Emphasis in the original)

If, as I argue above, representation can be hollowed out of its human subject for consumerist pleasures, then that representation by extension can be "owned" and altered by anyone. It is where representation intersects with a subjective experience or identity that the politics resides. It is also a politics that is oftentimes untranslatable. Rey Chow writes about the "essential untranslatability from the subaltern discourse to imperialist discourse" (35), noting (as I have tried to articulate in different terms above) that "the question to ask is not whether we can return the native to her authentic origin, but what our fascination with the native means in terms of her irreversibility of modernity" (36). She argues that attempting to speak for the native in "new" historical accounts and "diversity" initiatives for example may render the native more "visible", yet it also "neutralizes the untranslatability of the native's experience and the history of that untranslatability" (37-8; emphasis added). 
To an extent these are revisitations of old questions and practices, yet if the public cultural and political discourse, even within the recent months during which this article was being written and edited, is anything to go by, in which old prejudices of racial hatred and conflict appear to have resurfaced, the re-engagement of cosmopolitan ethics, understanding and communication, beyond the policy-leading terminology of "openness to difference" and "diversity", may be more pressing than ever. A more effective cosmopolitical framework must be one through which we can explore a reflexive and nuanced politics of translation, not only of language but also of the affective experiences generated by everyday encounters with difference, some of which may well be untranslatable, both onscreen and off.

\section{Notes}

${ }^{1}$ Acknowledgement: thanks to Fraser Elliott for this reference.

2 The Face of Fu Manchu (Don Sharp, 1965); The Brides of Fu Manchu (Don Sharp, 1966); The Vengeance of Fu Manchu (Jeremy Summers, 1967); The Blood of Fu Manchu (Jesús Franco, 1968); The Castle of Fu Manchu (Jesús Franco, as Jess Franco, 1969).

3 "Post-exclusion era" refers to the Chinese Exclusion Act, a US federal law prohibiting Chinese immigration to the United States between 1882 and 1943; a piece of legislation that worked alongside anti-miscegenation laws prohibiting non-whites from marrying whites. The latter had an impact on Hollywood casting and screenwriting that has been addressed elsewhere (see, for example, Courtney).

${ }^{4}$ British East Asian actors share similar frustrations, such as on the occasion when in 2012 the Royal Shakespeare Company (RSC) omitted to cast any East Asian actors in their staging of The Orphan of Zhao, except for a maid and two dogs (see Thorpe).

\section{References}

Aloha. Directed by Cameron Crowe, Columbia Pictures, 2015.

Avatar: The Last Airbender. Created by Bryan Konietzko and Michael Dante DiMartino. Nickelodeon, 2005-2008.

Beck, Ulrich. Cosmopolitan Vision. 2004. Translated by Ciaran Cronin, Polity Press, 2006.

Beltran, Mary C. "The New Hollywood Racelessness: Only the Fast, Furious, (and Multiracial) Will Survive.” Cinema Journal, vol. 44, no. 2, 2005, pp. 50-67.

The Birth of the Dragon. Directed by George Nolfi, Groundswell Productions, 2016.

The Blood of Fu Manchu. Directed by Jesús Franco, Udastex Films, 1968.

Breakfast at Tiffany's. Directed by Blake Edwards, Paramount Pictures, 1961. 
The Brides of Fu Manchu. Directed by Don Sharp, Constantin Film, 1966.

Brown, Mark. "Film on Morecambe Cockle Picker Disaster Bought for UK Art Collections." The Guardian, 22 March 2016, www.theguardian.com/artanddesign/2016/mar/22/ film-isaac-julien-morecambe-cockle-picker-disaster-uk-public-art.

The Castle of Fu Manchu. Directed by Jesús Franco, as Jess Franco, Balcázar Producciones Cinematográficas, 1969.

Chan, Felicia. Cosmopolitan Cinema: Cross-Cultural Encounters in East Asian Film. I.B. Tauris, 2017.

---. "Filming China: Zhang Yimou's Shifting Visual Politics." The Chinese Chameleon Revisited, edited by Yangwen Zheng, Cambridge Scholars Publishing, 2013, pp. 26183.

Chang, Stewart. "Feminism in Yellowface." Harvard Journal of Law and Gender, vol. 38, 2015, pp. 235-68.

Cheah, Pheng. "The Cosmopolitical-Today." Cosmopolitics: Thinking and Feeling Beyond the Nation, edited by Pheng Cheah and Bruce Robbins, U of Minnesota P, 1998, pp. $20-41$.

Chow, Rey. Writing Diaspora: Tactics of Intervention in Contemporary Cultural Studies. Indiana UP, 1993.

Cloud Atlas. Directed by Lana Wachowski, Warner Bros. Pictures, 2012.

Courtney, Susan. Hollywood Fantasies of Miscegenation: Spectacular Narratives of Gender and Race. Princeton UP, 2004.

Doctor Strange. Directed by Scott Derrickson, Walt Disney Studios, 2016.

Dyer, Richard. White: Essays on Race and Culture. Routledge, 1997.

Evans, Alan. "Doctor Strange 'Whitewashing' Row Resurfaces with New Criticism of Swinton Casting." The Guardian, 4 Nov. 2016, www.theguardian.com/film/2016/ nov/04/doctor-strange-tilda-swinton-whitewashing-row.

The Face of Fu Manchu. Directed by Don Sharp, Hallam Productions, 1965.

The Fast and the Furious. Directed by Rob Cohen, Universal Pictures, 2001.

Ghost in the Shell. Directed by Rupert Sanders, Paramount Pictures, 2017.

The Goddess. Directed by Wu Yonggang, Linhua film, 1934.

The Good Earth. Directed by Sidney Franklin, Metro-Goldwyn-Mayer, 1937.

The Great Wall. Directed by Zhang Yimou, Universal Pictures, 2016. 
Grice, Helena, "Face-ing / De-face-ing Racism: Physiognomy as Ethnic Marker in Early Eurasian/Amerasian Women's Texts." Re-collecting Early Asian America: Essays in Cultural History, edited by Josephine Lee, Imogene L. Lim, and Yuko Matsukawa. Temple UP, 2002, pp. 255-70.

Hero. Directed by Zhang Yimou, Miramax Film, 2002.

Hollywood Chinese. Directed by Arthur Dong, Deep Focus Productions, 2007.

Ito, Robert B. "“A Certain Slant': A Brief History of Hollywood Yellowface.” Bright Lights Film Journal, 2 May 2014, brightlightsfilm.com/certain-slant-brief-historyhollywood-yellowface/\#.WP4ZJsm1veR.

Judou. Directed by Zhang Yimou, Miramax Film, 1990.

Juzwiak, Rich. "Tilda Swinton Sent Us Her Email Exchange with Margaret Cho about Doctor Strange, Diversity, and Whitewashing." Jezebel, 16 Dec. 2016, jezebel.com/tilda-swinton-sent-us-her-email-exchange-with-margaret-1790203875.

Kokas, Aynne. Hollywood Made in China. U of California P, 2017.

Kracauer, Siegfried. "The Little Shopgirls Go to the Movies." The Mass Ornament: Weimar Essays, translated and edited by Thomas Y. Levin, Harvard UP, 1995, pp. 291-306.

Lane, Jill. "ImpersoNation: Toward a Theory of Black-, Red-, and Yellowface in the Americas." PMLA, vol. 123, no. 5, 2008, pp. 1728-31.

The Last Airbender. Directed by M. Night Shyamalan, Paramount Pictures, 2010.

Le, Mike. "The Cloud Atlas Conversation: Yellowface, Prejudice, and Artistic License." Racebending.com, 12 Aug. 2012, www.racebending.com/v4/blog/cloud-atlasconversation-yellowface-prejudice-artistic-license/.

Loh, Genevieve Sharon. "No whitewashing of The Great Wall: Zhang Yimou on the Controversy About His New Film." Channel News Asia, 7 Dec. 2016, www.channelnewsasia.com/news/lifestyle/no-whitewashing-of-the-great-wall-zhangyimou-on-the-controversy-7674950.

Looking for Langston. Directed by Isaac Julien, Sankofa Video and Film Production, 1989.

Lopez, Lori Kido. "Fan Activists and the Politics of Race in The Last Airbender." International Journal of Cultural Studies, vol. 15, no. 5, 2012, pp. 431-45.

Lorde, Audre. Sister Outsider: Essays and Speeches. Crossing Press, 1984.

Malone, Mary. “Sweet and Sour Dragon.” Daily Mirror, 1 May 1968, p. 18.

Memoirs of a Geisha. Directed by Rob Marshall, DreamWorks Pictures, 2005. 
Meskimmon, Marsha. Contemporary Art and the Cosmopolitan Imagination. Routledge, 2011.

Metzger, Sean. "Charles Parsloe's Chinese Fetish: An Example of Yellowface Performance in Nineteenth-Century American Melodrama." Theatre Journal, vol. 56, no. 4, 2004, pp. $627-51$.

---. "Ice Queens, Rice Queens, and Intercultural Investments in Zhang Yimou's Turandot." Asian Theatre Journal, vol. 20, no. 2, 2003, pp. 209-17.

Molz, Jenni Germann. "Cosmopolitanism and Consumption." The Ashgate Research Companion to Cosmopolitanism, edited by Maria Rovisco and Magdalena Nowicka, Ashgate, 2011, pp. 33-52.

Nava, Mica. "Cosmopolitan Modernity: Everyday Imaginaries and the Register of Difference." Theory, Culture \& Society, vol. 19, no. 1-2, 2002, pp. 81-99.

Nguyen, Kevin. "With The Great Wall, Hollywood Has Made Whitewashing China's Problem." GQ, 16 Feb. 2017, www.gq.com/story/the-great-wall-whitewashing.

The Orphan of Zhao. Adapted for the stage by Gregory Doran. Royal Shakespeare Company, Stratford-upon-Avon, 2012-2013.

Papastergiadis, Nikos. Cosmopolitanism and Culture. Polity Press, 2012.

Parker, David. "Diaspora, Dissidence and the Dangers of Cosmopolitanism." Asian Studies Review, vol. 27, no. 2, 2003, pp. 155-79.

Porter, David. "Chinoiseries and the Aesthetics of Illegitimacy." Studies in EighteenthCentury Culture, vol. 28, 1999, pp. 27-54.

Pulver, Andrew. "Birth of the Dragon: Makers of Film About Bruce Lee Respond to 'Yellowface' Row." The Guardian, 17 Oct. 2016, www.theguardian.com/film/2016/oct/17/bruce-lee-birth-of-the-dragon-film-culturalappropriation-row.

Raftery, Brian. "Thanks to Twitter, Ghost in the Shell Never Stood a Ghost of a Chance." Wired.com, 3 Apr. 2017, www.wired.com/2017/04/thanks-twitter-ghost-shell-neverstood-ghost-chance/.

Raise the Red Lantern. Directed by Zhang Yimou, Orion Classics, 1991.

Rawnsley, Gary D., and Ming-Yeh T. Rawnsley, editors. Global Chinese Cinema: The Culture and Politics of Hero. Routledge, 2010.

Schoene, Bertolt. The Cosmopolitan Novel. Edinburgh UP, 2009.

Shaw-Williams, Hannah. "Doctor Strange's Erasure of Tibet is a Political Statement." Screen Rant, 30 Apr. 2016. screenrant.com/doctor-strange-china-tibet-ancient-one/ 
Smith, Kate. Chinoiserie: Commerce and Critical Ornament in $18^{\text {th }}$ Century Britain. Manchester UP, 2014.

Spencer, Robert. Cosmopolitan Criticism and Postcolonial Literature. Palgrave Macmillan, 2011.

Spirited Away. Directed by Hayao Miyazaki, Toho, 2001.

Stacey, Jackie. "Crossing Over with Tilda Swinton: The Mistress of 'Flat Affect'." International Journal of Politics, Culture, and Society, vol. 28, no. 3, 2015, pp. 24371.

---. "On Being Open to Difference: Cosmopolitanism and the Psychoanalysis of Groups." Writing Otherwise: Experiments in Cultural Criticism, edited by Jackie Stacey and Janet Wolff. Manchester UP, 2013, pp. 45-60.

---. "The Uneasy Cosmopolitans of Code Unknown." Whose Cosmopolitanism?: Critical Perspectives, Relationalities and Discontents, edited by Nina Glick Schiller and Andrew Irving, Berghahn, 2015, pp. 160-74.

Star Trek. Created by Gene Roddenberry, NBC, 1966-69.

Sun, Rebecca. “An Open Letter to Tilda Swinton About Her Doctor Strange Whitewashing Email to Margaret Cho." The Hollywood Reporter, 21 Dec. 2016, www.hollywoodreporter.com/heat-vision/doctor-strange-whitewashing-an-openletter-tilda-swinton-958212.

Ten Thousand Waves. Directed by Isaac Julien, 2010.

Thorpe, Ashley. "Casting Matters: Colour Trouble in the RSC's The Orphan of Zhao." Contemporary Theatre Review, vol. 24, no. 4, 2014, pp. 436-51.

Turandot. Adapted for the stage by Zhang Yimou, 1998.

The Vengeance of Fu Manchu. Directed by Jeremy Summers, Warner Bros. Company, 1967.

Wang, Yiman. "The Art of Screen Passing: Anna May Wong's Yellow Yellowface Performance in the Art Deco Era." Camera Obscura, vol. 20, no. 3 60, 2005, pp. 15891.

Wong, Julia Carrie. “Asian Americans Decry 'Whitewashed' Great Wall Film Starring Matt Damon.” The Guardian, 30 July 2016, www.theguardian.com/film/2016/ju1/29/thegreat-wall-china-film-matt-damon-whitewashed.

Yang, Mina. "East Meets West in the Concert Hall: Asians and Classical Music in the Century of Imperialism, Post Colonialism, and Multiculturalism." Asian Music, vol. 38, no. 1, 2007, pp. 1-30. 
Yoshida, Emily. "Ghost in the Shell and Anime's Troubled History with Representation." The Verge, 9 May 2016, www.theverge.com/2016/5/9/11612530/ghost-in-the-shellanime-asian-representation-hollywood.

\section{Suggested Citation}

Chan, Felicia. "Cosmopolitan Pleasures and Affects; Or Why Are We Still Talking about Yellowface in Twenty-First-Century Cinema?" Alphaville: Journal of Film and Screen Media, no. 14, Winter 2017, pp. 41-60. www.alphavillejournal.com/Issue14/ArticleChan.pdf. ISSN: 2009-4078.

Felicia Chan is Senior Lecturer in Screen Studies at the University of Manchester where she researches the construction of national, cultural and cosmopolitan imaginaries in film. She is author of Cosmopolitan Cinema: Cross Cultural Encounters in East Asian Film (2017), coeditor of Chinese Cinemas: International Perspectives (2016), and founding member of the Chinese Film Forum UK. 